\title{
AKTIVITAS DAN HABITUASI KEAGAMAAN SISWA SDIT NIDAUL HIKMAH
}

\author{
Khikayah, Heru Prastyo \\ IAIN Salatiga \\ khikayah3@gmail.com, heruprastyo99@iainsalatiga.ac.id
}

\begin{abstract}
Abstrac
This is a qualitative study which aims to determine the religious activities and habituation as well as contributions of SDIT Nidaul Hikmah Students in 2018. Data collection, uses interview, observation and documentation methods. The technique of data analysis interactive data analysis, which consists of data reduction, data display, and conclusion or verification

The results of the study explain that religious activities carried out at SDIT Nidaul Hikmah Salatiga in 2018 are: religious lectures, PHBI and religious practices in the form of dhuha prayer, tahfidz, and congregational prayer (Dhuhur and Azhar). Religious activities which contribute to students are such as: 1) instilling habitual worship, 2) fostering discipline, and familiarizing students to live close to religion, 3) habituation of children to behave according to the values of Islamic teachings, honesty, responsibility and behaviour.

It concluded that activities and habituations give positive contribution to students iof SDIT Nidaul Hikmah in the form of discipline, honesty, responsibility and behavior in accordance with the values of Islamic teachings.
\end{abstract}

Keywords: activity, habituation, religion.

\begin{abstract}
Abstrak
Penelitian ini bertujuan untuk mengetahui aktivitas dan habituasi serta kontribusi keagamaan Siswa SDIT Nidaul Hikmah Tahun 2018. Jenis penelitian ini adalah termasuk penelitian kualitatif. Pengumpulan data ini menggunakan metode wawancara, observasi, dan dokumentasi. Teknik analisis data menggunakan analisis data interaktif, yaitu : reduksi data, display data, dan kesimpulan atau verifikasi

Hasil penelitian memaparkan bahwa aktifitas keagamaan yang dilakukan di SDIT Nidaul Hikmah Kota Salatiga Tahun 2018 berupa: ceramah keagamaan, PHBI dan pengamalan ajaran agama berupa: shalat
\end{abstract}


dhuha, tahfidz, dan shalat berjamaah (Dhuhur, dan Azhar). Aktivitas keagamaan berkontribusi bagi diri siswa antara lain :1) menanamkan pembiasaan beribadah, 2) menumbuhkan kedisiplinan, dan membiasakan siswa hidup dekat dengan agama, 3) pembiasaan anak berperilaku sesuai nilai- nilai ajaran Islam, jujur, bertanggung jawab dan berkarakter.

Kesimpulan penelitian ini adalah aktivitas dan habituasi memberikan kontribusi yang positif pada diri siswa di SDIT Nidaul Hikmah yang berupa kedisiplinan, kejujuran, tanggung jawab dan perilaku sesuai dengan nilai-nilai ajaran Islam.

Kata Kunci: aktivitas, habituasi, keagamaan

\section{A. PENDAhuluan}

Undang-undang Nomor 20 Tahun 2003 tentang Sistem Pendidikan Nasional mengamanatkan bahwa pendidikan di Indonesia bertujuan untuk mengembangkan potensi peserta didik agar menjadi manusia yang beriman dan bertaqwa kepada Tuhan Yang Maha Esa, berakhlak mulia, cakap, kreatif, mandiri, menjadi warga negara yang demokratis dan bertanggung jawab. ${ }^{1}$

Sejalan dengan tujuan tersebut, dalam Bab X Pasal 36 disebutkan bahwa kurikulum yang disusun sesuai dengan jenjang pendidikan dalam kerangka Negara Kesatuan Republik Indonesia hendaklah memperhatikan beberapa hal, diantaranya peningkatan iman dan takwa, peningkatan akhlak mulia dan agama.

Lebih khusus lagi ditegaskan dalam Peraturan Pemerintah Nomor 55 Tahun 2007 tentang Pendidikan Agama dan Pendidikan Keagamaan Pasal 1 dan 3 bahwa pendidikan agama wajib diselenggarakan pada semua jalur, jenjang, dan jenis pendidikan. ${ }^{2}$ Ketentuan ini menempatkan

${ }^{1}$ Republik Indonesia, Undang-Undang Nomor 20 Tahun 2003 tentang Sistem Pendidikan Nasional, (Jakarta: Departemen Agama R.I., Direktorat Jenderal Pendidikan Islam, 2007), 5.

${ }^{2}$ Republik Indonesia, Peraturan Pemerintah Nomor 55 Tahun 2007 tentang Pendidikan Agama dan Pendidikan Keagamaan,(22 April 2010). 
pendidikan agama pada posisi yang amat strategis dalam upaya mencapai tujuan pendidikan yang diharapkan. Perintah tentang pentingnya pendidikan agama tertera dalam firman Allah SWT yang terdapat dalam surat At Taubah ayat 122:

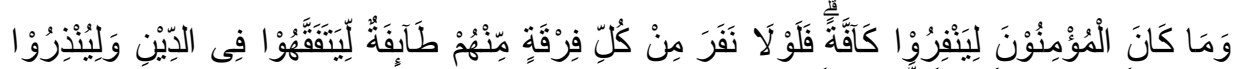

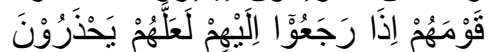

Artinya: Dan tidak sepatutnya orang-orang mukmin itu semuanya pergi (ke medan perang). Mengapa sebagian dari setiap golongan di antara mereka tidak pergi untuk memperdalam pengetahuan agama mereka dan untuk memberi peringatan kepada kaumnya apabila mereka telah kembali, agar mereka dapat menjaga dirinya.

Ayat tersebut menegaskan bahwa memperdalam ilmu agama itu merupakan kewajiban bagi setiap manusia sebagai bekal untuk menjaga diri sehingga menghasilkan karakter yang Islami.

Selain hal di atas guna menghindari semakin rusaknya komitmen berkepribadian sehat, maka diperlukan pengembangan model pendidikan nilai-nilai keberagamaan dalam membina kepribadian sehatsiswa yang bisa diimplementasikan di sekolah danberdasarkan pada beberapa alasan sebagai berikut:(1) Peranan guru Pendidikan Agama Islam (PAI) dalam mengembangkan model pendidikan nilai-nilai keberagamaan dalam membina kepribadian sehat, sangat mengkristalkarena menekankan kepada perwujudan sikap,perilaku dan pribadi yang sehat, akhlak mulia,beriman dan bertakwa kepada Allah SWT; 2) Orang tuanya bersikap keras atau kurang memberikan curahan kasih sayang kepada anaknya. Sebagaimana hasil penelitian bahwa tawuran,penyalahgunaan obat terlarang, dan tindakan kriminal di kalangan remaja, disebabkan tidak adanya komunikasi yang lebih baik antara keluarga, sekolah,dan masyarakat. Sehingga nilai-nilai keagamaan yang diajarkan di sekolah sebagai suatu konsep yang ideal, berhadapan dengan realita di masyarakat 
yang bertolak belakang dengan eksistensi pemahaman keberagamaan siswa di sekolah. ${ }^{3}$

Pendidikan Agama Islam di Indonesia dewasa ini mendapatkan sorotan tajam dari masyarakat, khususnya dalam membentuk peserta didik yang beriman dan bertaqwa. Nurkhalis Majid mengatakan bahwa kegagalan Pendidikan Agama Islam disebabkan pembelajaran PAI lebih menitikberatkan pada hal-hal yang bersifat formal dan hafalan, bukan pada pemaknaannya. ${ }^{4}$

Demikian juga dalam upaya meningkatkan mutu pendidikan, PAI harus dijadikan tolak ukur dalam membentuk watak dan pribadi peserta didik, serta membangun moral bangsa (nation character building). ${ }^{5}$ Bagi penulis, proses membangun karakter bangsa ini perlu dilakukan dengan berbagai langkah dan upaya yang sistemik. Akhlak sebagai salah satu bagian terpenting dalam pendidikan hendaknya menjadi fokus utama dalam upaya pembentukan menjadi manusia dewasa yang siap untuk mengembangkan potensi yang dibawa sejak lahir. Pendidikan akhlak diharapkan akan mampu mengembangkan nilai-nilai yang dimiliki peserta didik menuju manusia dewasa yang berkepribadian sesuai dengan nilai-nilai Islam.

\section{B. AKTIVITAS KEAGAMAAN}

${ }^{3}$ Dewi Sadiah, "Pengembangan Model Pendidikan Nilai-Nilai Keberagamaan Dalam Membina Kepribadian Sehat", Jurnal Penelitian Pendidikan, Volume 11, Nomor 2 (Oktober 2010), 98-99.

${ }^{4}$ Abdul Majid \& Dian Andayani, Pendidikan Agama Islam Berbasis Kompetensi, (Bandung: Rosda Karya, 2005), 165.

${ }^{5}$ Muhammad Alim, Pendidikan Agama Islam; Upaya Pembentukan Pemikiran dan Kepribadian Muslim, Cet. I, (Bandung: Remaja Rosdakarya, 2006), 8. 
Soejono Soekanto ${ }^{6}$ dalam bukunya, Kamus Sosiologi mendefinisikan aktifitas sebagai tanggapan yang terorganisasi. Sementara keagamaan menurut WJS Poerwadarminta ${ }^{7}$ adalah segala sesuatu mengenai agama. Berdasarkan kedua pendapat tersebut maka definisi tersebut maka aktifitas keagamaan adalah tanggapan secara terorganisasi terhadap segala bentuk kegiatan yang terencana dan terkendali berhubungan dengan usaha untuk menanamkan bahkan menyebarluaskan nilai-nilai keagamaan yang pelaksanaannya dapat dilakukan oleh perorangan maupun kelompok.

Beberapa bentuk aktivitas keagamaan tersebut, ${ }^{8}$ antara lain:

1. Aktivitas siswa terhadap pengajian (ceramah) agama

Kajian ini bertujuan untuk memberikan pengetahuan keagamaan bagi siswa, sehingga siswa tersebut memperoleh dan mempunyai pengetahuan keagamaan yang memadai dan sebagai penambah nilainilai kerohanian dalam jiwa mereka.

Aktivitas siswa dalam kegiatan ini sangat besar artinya dalam perkembangan batiniyah mereka sebab mereka berada pada usia remaja. Remaja dengan segala latar belakangnya justru akan memberikan warna tersendiri bagi penyelenggaraan ceramah agama ini, karena dari mereka ini akan bermunculan berbagai ide-ide yang praktis dan bersifat konstruktif dalam meningkatkan kegiatan keagamaan yang diselenggarakan. Di samping kegiatan-kegiatan tersebut di atas dapat mengisi waktu yang lowong bagi siswa, juga aktivitas ini dapat menambah pengetahuan dan memperdalam

${ }^{6}$ Soejono Soekanto, Kamus Sosiologi, (Jakarta: Rajawali Press, 1989), 15.

${ }^{7}$ W. J.S. Poerwadarminta, Kamus Umum Bahasa Indonesia, (Jakarta: Balai Pustaka, 1984), 19.

${ }^{8}$ Dirjen Bimbingan Islam, Petunjuk Pelaksanaan Kurikulum Sekolah Menengah Umum/GBPP Mata Pelajaran Agama Islam, (Jakarta, Departemen Agama RI, 1997), 2. 
pengetahuan agama yang dimiliki oleh para siswa, dan yang terpenting ialah untuk membantu mereka dalam pembinaan moral agama siswa itu sendiri.

Dengan adanya kegiatan ini siswa diharapkan akan menjadikan dirinya sebagai harapan semua demensi dalam kehidupan, karena dalam kegiatan ceramah agama ini selalu ada wejangan-wejangan yang bersifat mengisi khazanah rohaniah mereka sejalan dengan ajaran moral, etika dan agama Allah, sehingga pada akhirnya akan memperkecil kemungkinan mereka terjatuh ke jurang kecelakaan dan kesesatan.

2. Aktivitas Siswa dalam Kegiatan Peringatan Hari-hari Besar Islam (PHBI)

Peringatan Hari-hari Besar Islam (PHBI) mempunyai arti penting bagi perkembangan syiar ke-Islaman, karena dari sinilah umat Islam itu sendiri menampakkan jati dirinya sebagai seorang muslim yang menghargai nilai-nilai historis agamanya. Di samping itu pula peringatan hari-hari besar Islam ini adalah merupakan manifestasi dari nilai-nilai keimanan seseorang.

Aktivitas ini mempunyai tujuan penting, yaitu untuk mengenang kejadian maupun peristiwa yang terdahulu pernah terjadi di kalangan umat Islam, hal ini sangat berguna untuk mempertebal keimanan dan tentunya ketakwaan kepada Allah SWT.

Siswa dalam hal ini adalah bagian integral dari masyarakat pada umumnya, yang merupakan cikal bakal bagi generasi penerus, haruslah mempunyai rasa memiliki atas kegiatan ini. Oleh karena itulah kegiatan tersebut akan semakin nampak kemeriahannya, kesemarakannya dengan kehadiran para siswa ini. Dengan kata lain 
kehadiran siswa dalam penyelenggaraan PHBI ini mempunyai nilai tambah bagi kemajuan syiarsyiar agama Islam.

3. Aktivitas Siswa dalam Pengamalan Ajaran Agama

Tingkah laku, perbuatan serta sikap siswa, baik dalam kehidupan bermasyarakat di mana ia tinggal maupun di lingkungan di mana ia mengenyam ilmu pengetahuan, akan didapati banyak bahkan merupakan keharusan untuk melibatkan dirinya dalam berbagai kegiatan bernuansa keagamaan. Dari sinilah akan nampak pengamalan ajaran-ajaran agama, misalnya mereka bertadarus $\mathrm{Al}$ Qur'an, menghafal Al Quran shalat berjama'ah, shalat dhuha mengadakan Pesantren Ramadhan, turut aktif dalam penyelenggaraan peringatan hari-hari besar Islam, maupun shalat sunat rawatib yang dikerjakan sendiri.

Segala aktivitas siswa tersebut akan dapat berhasil apabila lingkungan keluarga (dalam hal ini) kedua orang tuanya tidak melepaskan tanggung jawabnya sebagai pendidik hakiki, yang dimaksud di sini ialah orang tuanya jangan bersifat apatis terhadap perkembangan anaknya dan hanya terpaku terhadap lembaga pendidikan anak tersebut. Di sini dikehendaki adanya saling kerjasama antara orang tua dan lembaga pendidikan tersebut. Dalam hal ini dapat dilakukan orang tua dengan menanyakan tentang perkembangan anaknya sendiri di mana akan menuntut ilmu, sebab bagaimanapun juga anak tersebut (siswa) lebih banyak tinggal di lingkungan rumah tangganya dibandingkan kehidupan di luar (sekolah). 


\section{HABITUASI KEAGAMAAN}

Habitus merupakan kecenderungan yang ajeg dan belangsung lama dan dapat diterapkan di ranah yang berbeda. Meskipun ajeg namun habitus bersifat lentur dan dapat diubah atau fleksibel sesuai lingkungannya ${ }^{9}$. Untuk menjadikan seseorang itu belajar haruslah kita memberikan syaratsyarat tertentu, yang terpenting menurut teori ini ialah latihan-latihan secara terus menerus, dalam teori ini yang diutamakan ialah belajar yang terjadi secara otomatis. ${ }^{10}$ Proses ini akan menjelmakan kebiasaan (habit) dan kemampuan (ability), yang akhirnya akan menjadi sifat-sifat pribadi (personal habits) yang terperangai dalam perilaku sehari-hari. ${ }^{11}$

Dalam psikologi, proses pembiasaan disebut "conditioning”. Dalam teori Conditioning (Ivan Pavlov dan Watson), belajar adalah formasi kebiasaan yang diakibatkan oleh persyaratan (conditioning) atau menghubungkan stimulus yang lebih kuat dengan stimulus yang lebih lemah hingga akhirnya organisme itu dimungkinkan, sebagai hasil dari pada belajar asosiatif, hal ini untuk mentransfer respon yang biasanya dihubungkan dengan stimulus yang lebih kuat dihentikan. ${ }^{12}$ Menurut teori Conditioning ini belajar juga diartikan dengan suatu proses perubahan yang terjadi karena adanya syarat (conditions) yang kemudian menimbulkan reaksi (respon).

\footnotetext{
${ }^{9}$ Bourdieu, P., Menyingkap Kuasa Simbol. Terj. Fauzi Fashri. (Yogyakara: Jalan sutra, 1992), 101.

${ }^{10}$ Sumadi Sueyabrata, Psikologi Pendidikan,(Jakarta: Rajawali press, 1984), 284.

${ }^{11}$ Hanna Djumhana, Integrasi Psikologi dengan Islam Menuju Psikologi Islami, (Yogyakarta: Yayasan Insan Kamil dan Pustaka Pelajar, 2001), 6.

${ }^{12}$ A. Crow \& L Crow, Psikologi Pendidikan, Nur Cahaya, 1989, 280.
} 
Habituasi adalah membiasakan kebiasaan sebagai pembaruan baru yang seimbang dengan perbaikan yang terus menerus yang menciptakan spiral pertumbuhan yang meningkat yang akan memberi hasil jangka panjang yang menguntungkan. Pembiasaan menulis akan berdampak baik untuk membangun kompetensi siswa di masa depan ${ }^{13}$.

Kemendikbud menyatakan bahwa pembiasaan adalah proses pembentukan sikap dan perilaku yang relatif tetap dan bersifat otomatis melalui kegiatan pembelajaran yang berulang-ulang. Hal ini disampaikan dalam salinan Peraturan Menteri Pendidikan dan Kebudayaan Tentang penumbuhan Budi Pekerti tahun 2015 (Peraturan Menteri Pendidikan dan Kebudayaan RI tentang Penumbuhan Budi Pekerti, Nomor 23 Tahun $2015,2015)$. Oleh sebab itu, istilah habiatuasi sangat berhubungan erat dengan sikap dan etika.

Pembiasaan juga diartikan melakukan suatu perbuatan atau ketrampilan tertentu secara terus-menerus dan konsisten untuk waktu yang cukup lama, sehingga perbuatan atau ketrampilan itu benar-benar dan akhirnya menjadi suatu kebiasaan yang sulit ditinggalkan. Oleh karena itu, sebagai awal dalam proses pendidikan, pembiasaan merupakan cara yang sangat efektif dalam menanamkan nilai-nilai moral ke dalam jiwa anak yang kemudian akan termanifestasikan dalam kehidupan sampai dewasa. ${ }^{14}$ Dalam kaitannya dengan metode pengajaran dalam pendidikan Islam, dapat dikatakan pembiasaan adalah sebuah cara yang dapat dilakukan untuk membiasakan anak didik berfikir, bersikap dan bertindak sesuai dengan tuntutan ajaran agama Islam. ${ }^{15}$

\footnotetext{
${ }^{13}$ Fitri Amilia, "Pemahaman dan Habituasi untuk Membangun Kompetensi Menulis Praktis dan Ilmiah" Jurnal Bahasa, Sastra, dan Pengajarannya, Volume 6, Nomor 1 (Februari 2018), 28.

${ }^{14}$ Armai Arief, Pengantarilmu dan Metodologi..., 109.

${ }^{15}$ Binti Maunah, Metodologi Pengajaran Agama Islam, (Yogyakarta: Teras, 2009), 93.
} 
Kegiatan pembiasaan merupakan bagian dari proses dalam pembelajaran yang secara umum dapat dipahami sebagai tahapan perubahan seluruh tingkah laku individu yang relatif menetap sebagai hasil pengalaman dan interaksi dengan lingkungan yang melibatkan proses kognitif. ${ }^{16}$ Pembelajaran dalam pengertian yang digunakan di sini adalah sebuah proses atau aktivitas yang menunjukkan pada proses perubahan yang diinginkan di dalam tingkah laku manusia.

Selain itu habituasi juga mempunyai arti proses penciptaan aneka situasi dan kondisi (persistent life situation) yang berisi aneka penguatan (reinforcment) yang memungkinkan peserta didik pada satuan pendidikannya, dirumahnya, di lingkungan masyarakatnya membiasakan diri berperilaku sesuai nilai dan menjadikan perangkat nilai yang telah diinternalisasi dan dipersonalisasi melalui proses ulu hati, olah dikir, olah raga, olah rasa, da karsa itu sebagai karakter atau watak. ${ }^{17}$

Pendidikan Agama Islam di Indonesia dewasa ini mendapatkan sorotan tajam dari masyarakat, khususnya dalam membentuk peserta didik yang beriman dan bertaqwa. Nurkhalis Majid mengatakan bahwa kegagalan Pendidikan Agama Islam disebabkan pembelajaran PAI lebih menitikberatkan pada hal-hal yang bersifat formal dan hafalan, bukan pada pemaknaannya. ${ }^{18}$ Maka penting dalam pendidikan Islam mengedepankan strategi pembelajaran yang bersifat implementatif sehingga lebih dapat membentuk peserta didik yang beriman dan bertaqwa. Berpijak penjelasan tersebut penting melakukan penelitian

\footnotetext{
${ }^{16}$ Muhibin Syah, Psikologi Pendidikan dengan Pendekatan Baru, (Bandung: Remaja Rosda Karya, 2003), 41.

${ }^{17}$ Haris Munandar, "Pola Pembinaan Keagamaan Di SMA Plus Boarding School Astha Hannas Subang”, Jurnal Tarbiyah, Volume 25, Nomor 1, (Januari 2018), 30.

${ }^{18}$ Abdul Majid \& Dian Andayani, Pendidikan Agama Islam Berbasis Kompetensi, (Bandung: Rosda Karya, 2005), 165.
} 
Jurnal Pendidikan Agama Islam Universitas Wahid Hasyim Semarang

tentang penelitian tentang sejauhmana aktivitas dan habiatuasi keagamaan dalam membentuk peserta didik yang beriman dan bertaqwa.

Berikut penulis membuat kerangka berpikir dalam penelitian ini:

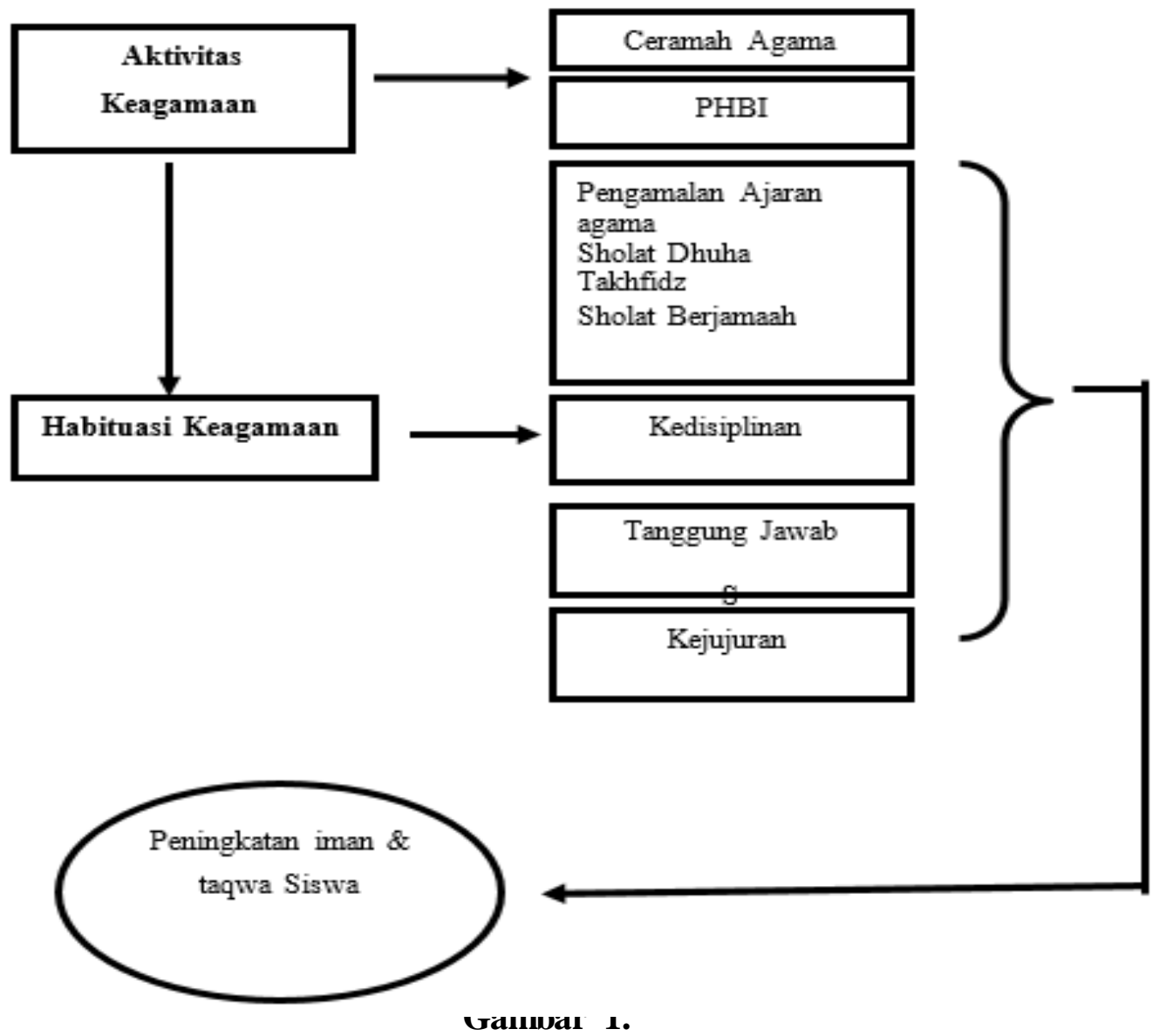

\section{Aktivitas dan Habituasi Keagamaan Siswa SDIT Nidaul Hikmah}

Gambar tersebut menggambarkan aktivitas keagamaan siswa bahwa untuk meningkatkan Iman dan Taqwa siswa dapat dilakukan melalui strategi kegiatan pembiasaan (habituation), artinya Keimanan dan ketaqwaan siswa terbentuk dari pembiasaan-pembiasaan yang setiap hari dilakukan. 


\section{METODE PENELITIAN}

Jenis penelitian ini adalah penelitian kualitatif. Pendekatan kualitatif ini berkiblat pada pemikiran Weber yang menyatakan bahwa penelitianpenelitian sosial bukan semata-mata memfokuskan pada gejalagejala sosial yang tampak, tetapi pada makna-makna latent di balik perilaku dan interaksi sosial tersebut. ${ }^{19}$

Metode pengumpulan data yang dilakukan adalah Observasi, dokumentasi dan wawancara. Observasi adalah pengamatan secara langsung di lapangan terhadap aktifitas dan habituasi keagamaan. Dokumentasi adalah dokumen-dokumen yang diperoleh di sekolah baik berupa catatan aktifitas dan habituasi keagamaan dan foto. Wawancara yaitu usaha mengumpulkan informasi dengan mengajukan sejumlah pertanyaan secara lisan untukdijawab secara lisan pula. Jenis wawancara yang digunakan peneliti adalah jenis wawancara terpimpin, yaitu wawancara yang dilakukan oleh pewawancara dengan membawa sederetan pertanyaan lengkap dan terperinci. ${ }^{20}$

Wawancara dalam penelitian ini dilakukan peneliti dengan menggunakan panduan pertanyaan yang sesuai dengan tujuan penelitian ini, yaitu: 1) Mengetahui aktifitas keagamaan siswa di SDIT Nidaul Hikmah, 2) Mengetahui habiatuasi keagamaan siswa di SDIT Nidaul Hikmah.3) Mengetahui kontribusi aktivitas dan habitusi keagamaan siswa di SDIT Nidaul Hikmah.

\footnotetext{
${ }^{19}$ Mundir, Metode Penelitian Pendidikan,... 211.

${ }^{20}$ S ugiyono, Statistika Untuk Penelitian,(Bandung: Alfabeta, 2006), 164.
} 
Pegecekan keabsahan data menggunakan triangulasi. Pengecekan keabsahan data dengan Trianggulasi Tekhnik,. Trianggulasi tekhnik dilakukan dengan cara mengecek data dengan sumber yang sama dengan tekhnik yang berbeda yang diperoleh dengan observasi.

Secara umum, penelitian kualitatif dalam melakukan analisis data banyak menggunakan model analisis yang dicetuskan oleh Miles dan Huberman yang sering disebut dengan metode analisis data interaktif. Aktivitas dalam analisis data kualitatif ada tiga, yaitu tahap reduksi data, display data, dan kesimpulan atau verifikasi. ${ }^{21}$

\section{E. HASIL PENELITIAN}

\section{AKTIVITAS KEAGAMAAN SDIT NIDAUL HIKMAH}

a. Program Aktivitas Keagamaan Siswa

Tujuan dari pendidikan agama adalah membentuk karakter pada diri siswa. Salah keunggulan yang dimiliki SDIT dalam rangka membentuk karakter islami siswa adalah adanya program aktivitas keagamaan siswa. Ada beberapa program aktivitas keagamaan di SDIT Nidaul Hikmah diantaranya adalah sholat dhuha, takhfidz dan sholat berjamaah. Program ini sudah dicanangkan sejak SDIT ini berdiri. Penjelasan tersebut diperoleh dari hasil wawancara dengan Ibu Narsini selaku Koordinator Waka PAI.

"Sejak awal berdiri kami sudah ada program kegiatan sholat dhuha, takhfidz dan sholat berjamaah, program tersebut adalah kekhasan yang ada di kurikulum kami”.

Agar anak terbiasa dengan kegiatan keagamaan perlu adanya program-program yang harus dicanangkan dan dilaksanakan.

${ }^{21}$ Sugiyono, Statistika ..., 164. 
Pembelajaran keagamaan tidak sekedar materi yang diajarkan tetapi lebih kepada praktek. Meskipun anak sudah tahu secara teori tetapi keberhasilan suatu pendidikan perlu didukung oleh lingkungan sekitar. Hal ini sesuai dengan Teori konvergensi menurut Purwanto ${ }^{22}$ menerangkan bahwa:

"Hasil pendidikan anak-anak ditentukan oleh dua faktor yakni pembawaan dan lingkungan".

Jadi, meskipun anak itu mempunyai pemahaman bila tidak dikembangkan secara baik dan benar akan sia-sia. Pengembanga n secara baik dan benar akan menjadi pondasi yang kuat untuk pembelajaran selanjutnya. Pendidikan tidak hanya mementingk an kecerdasan intelektual saja melainkan moral dan nilai menjadikan rujukan yang penting untuk dikembangkan kepada peserta didik dijaman yang semakin tidak batas perilaku antara orang satu dengan orang lain.

Hasil dari observasi bahwa di SDIT Nidaul Hikmah telah ada program kegiatan keagamaan yang harus dilaksanakan secara oleh siswa. Hal ini dibuktikan adanya aktivitas rutin kegiatan keagamaan tersebut.

b. Tujuan Aktivitas Keagamaan Siswa

Berdasarkan Tulisan di Harvard University Amerika Serikat (Ali Ibrahim Akbar, dalam Winarno Narmoatmojo, 2009/2010), ternyata kesuksesan seseorang tidak ditentukan semata-mata oleh pengetahuan dan kemampuan teknis (hard skill) saja, tetapi lebih oleh kemampuan mengelola diri dan orang lain (soft skill). Tulisan ini mengungkapkan, kesuksesan hanya ditentukan sekitar 20

\footnotetext{
${ }^{22}$ M.Ngalim Purwanto, Ilmu Pendidikan Teoritis dan Praktis. (Bandung: Remaja Rosdakarya, 2002), 15.
} 
persen oleh hard skill dan sisanya 80 persen oleh soft skill. Bahkan orang-orang tersukses di dunia bisa berhasil dikarenakan lebih banyak didukung kemampuan soft skill daripada hard skill. ${ }^{23}$

Adanya aktivitas kagamaan yang harus dilaksanakan oleh setiap individu diharapokan terbentuk pribadi yang berkarakter. Dunia pendidikan saat ini mulai krisis karakter, oleh karena itu perlu terobosan- terobosan baru untuk membentuk karakter siswa salah satunya dengan pembiasaan aktivitas keagamaan.

Dari hasil wawancara kami dengan guru SDIT Nidaul Hikmah bahwa aktivitas keagamaan yang diprogramkan memiliki beberapa tujuan yaitu untuk menanamkan pembiasaan beribadah pada diri siswa, sehingga diharapkan ke depannya siswa terbiasa melakukan ibadah harian sebagai bekal untuk kehidupannya. Penjelasan tersebut diperoleh dari hasil wawancara dengan Ibu Narsini selaku Koordinator Waka PAI,

"Aktivitas ini dilakukan dengan tujuan untuk menanamkan pembiasaan beribadah pada diri siswa, sehingga diharapkan ke depannya siswa terbiasa melakukan ibadah harian sebagai bekal untuk kehidupannya"24

Tujuan lain dari aktivitas keagamaan yang dilakukan di SDIT Nidaul Hikmah Salatiga adalah menumbuhkan kedisiplinan beribadah, dan membiasakan siswa untuk hidup dekat dengan agama. Penjelasan tersebut diperoleh dari hasil wawancara dengan Ibu Tri Lestari Ningsih selaku guru kelas V, adalah:

"Aktivitas keagamaan yang selama ini menjadi program sekolah bertujuan untuk menumbuhkan kedisiplinan beribadah, dan membiasakan siswa untuk hidup dekat dengan agama" 25

23 Winarno Narmoatmojo, Ekstrakurikuler di Sekolah Dasar Kebijakan dan Aktualisasinya, http://winarno.staff.fkip.uns.ac.id/ files/2009/10.

24Ibu Narsini selaku Koordinator Waka PAI, wawancara tanggal 27 Juli 2018

25 Tri Lestari Ningsih selaku Wali Kelas V, wawancara tanggal 27 Juli 2018 
Sementara hasil wawancara dengan Ibu Wiwik Nugrahanti selaku Waka Kesiswaan, bahwa tujuan program aktivitas keagamaan diantaranya adalah membiasakan anak berperilaku baik. Berikut hasil wawancaranya:

"Membiasakan anak berperilaku baik sebab anak seusia anak SD belum menyadari apa yang disebut baik dan tidak baik, perhatian mereka lekas dan mudah beralih kepada hal-hal baru dan disukainya" 26

Berdasarkan hasil wawancara tersebut maka tujuan dari aktivitas keagamaan yang menjadi salah satu program di SDIT Nidaul Hikmah Salatiga dapat dirangkum sebagai berikut: 1) Untuk menanamkan pembiasaan beribadah pada diri siswa, 2) Menumbuhkan kedisiplinan beribadah, dan membiasakan siswa untuk hidup dekat dengan agama, 3) Membiasakan anak berperilaku baik. Hal ini sesui pernyataan $\mathrm{Mc} \mathrm{Phail}^{27}$

"Discipline must be instilled and nurtured in the child, so that eventually a sense of discipline that will grow from the hearts, the children themselves (self-disipline) Therefore, teachers in instilling discipline in students should pay attention to some of the measures"

c. Fungsi Aktivitas Keagamaan

Dari hasil wawancara kami dengan Ibu Narsini selaku Koordinator Waka PAI diperoleh keterangan fungsi dari aktivita s keagamaan itu sendiri adalah membentuk dan mengembangkan fitrah siswa agar berpikiran baik, berhati baik, dan berperilaku sesuai dengan nilai-nilai agama Islam, membentuk siswa yang 
bertanggung jawab, dan berkarakter. Berikut kutipan wawancara dengan Ibu Narsini selaku Koordinator Waka PAI,

"Fungsi dari aktivitas keagamaan itu sendiri untuk membentuk dan mengembangkan fitrah siswa agar berpikiran baik, berhati baik, dan berperilaku sesuai dengan nilai-nilai agama Islam, membentuk siswa yang bertanggung jawab, dan berkarakter" 37

Hasil penelitian menunjukkan bahwa aktifitas keagamaan yang dilakukan di SDIT Nidaul Hikmah Kota Salatiga berupa, sholat dhuha, takhfidz, dan sholat Berjamaah (dhuhur, dan asar). Tujuan dari pelaksanaan aktivitas keagamaan tersebut adalah 1) Untuk menanamkan pembiasaan beribadah pada diri siswa, 2) Menumbuhkan kedisiplinan beribadah, dan membiasakan siswa untuk hidup dekat dengan agama, 3) Membiasakan anak berperilaku baik. Sementara fungsi dari aktivitas keagamaan siswa tersebut adalah membentuk dan mengembangkan fitrah siswa agar berpikiran baik, berhati baik, dan berperilaku sesuai dengan nilainilai agama Islam, serta membentuk siswa yang bertanggung jawab dan berkarakter. Aktivitas keagamaan yang dilakukan di SDIT Nidaul Hikmah tersebut, yaitu Sholat Dhuha, Takhfidz, dan Sholat Berjamaah (Dhuhur, dan Ashar), sesuai dengan aktivita s keagamaan yang diungkapkan oleh Dirjen

Bimbagan Islam, bahwa aktivitas keagamaan salah satunya dapat berbentuk Pengamalan Ajaran Agama, misalnya bertadarus Al Qur'an, dan shalat berjama'ah ${ }^{28}$

\section{Habituadsi Keagamaan Siswa Sdit Nidaul Hikmah}

${ }^{28}$ Dirjen Bimbaga Islam, Petunjuk Pelaksanaan Kurikulum ..., 2. 
Untuk mengetahui sejauhmana keberhasilan dari aktivitas dan habituasi keagamaan yang selama ini dilakukan, maka pihak pendamping secara kontinyu mengamati perkembangan dari siswa itu sendiri, dengan memberikan catatan aktivitas dan habituasi keagamaan siswa pada buku evaluasi yang dipegang oleh masingmasing siswa. Selain pihak pendamping, pihak sekolah juga meminta orang tua siswa untuk melakukan evaluasi terhadap aktivitas dan habituasi keagamaan yang dilakukan siswa selama di rumah. Sebagai bukti orang tua juga memberikan paraf pada kolom yang telah disediakan pada buku evaluasi siswa.

Informasi tersebut di atas diperoleh wawancara peneliti dengan Ibu Narsini, berikut hasil wawancaranya:

"Mengetahui sejauhmana keberhasilan dari aktivitas dan habituasi keagamaan siswa, maka sekolah membuat buku evaluasi yang didalamnya berisi tentang aktivitas dan habituasi keagamaan siswa yang dilakukan setiap harinya, jika aktivitas dan habituasi dilakukan di sekolah maka guru koordinator yang memberikan paraf, tetapi jika aktivita dan habituasi dilakukan di rumah maka sekolah meminta orang tua untuk memberikan paraf. Hal tersebut merupakan cara kami untuk memantau sejauhmana perkembangan dari aktivitas dan habituasi keagamaan siswa secara pribadi". ${ }^{29}$

Informasi tersebut di atas diperoleh dari wawancara dengan berbagai sumber, yaitu: Ibu Narsini, Adinda Siswa Kelas V, Istiqomah Ibu dari Salah Seorang Siswa, dan Ibu Sri Mulyani selaku guru kelas IV, berikut kutipan wawancara mereka,

"Ya namanya anak-anak susah diaturnya, dibenak mereka maunya ya main terus, ....... jadi ya guru pendaping perlu kesabaran yang tinggi, "30

"Kadang lupa bawa rukuh......., jadi gantian dengan teman..."31

\footnotetext{
${ }^{29}$ Ibu Narsini selaku Koordinator Waka PAI, wawancara tanggal 27 Juli 2018

${ }^{30}$ Ibu Narsini selaku Koordinator Waka PAI,wawancara tanggal 27 Juli 2018

${ }^{31}$ Adinda selaku siswa kelas $V$, wawancara tanggal 27 Juli 2018
} 
"Kami suami istri kerja semua, pulang udah malem.....capek....ya gimana mau tahu aktivitas keagamaan anak di rumah....., saya juga baru-baru saja tahu dari sekolah kalo ada buku evaluasi aktivitas keagamaan siswa di rumah yang harus diparaf orang tua......"32 "Kendala sebenarnya dari sekolah, fasilitas wudhu misalkan saya rasa kurang memadai jika dibanding dengan jumlah siswa, misal: untuk aktivitas wudhu siswa 1 (satu) kelas dengan jumlah 25 anak, membutuhkan waktu 30 menit, kondisi tersebut tentu mengganggu kelancaran dari aktivitas dan habituasi keagamaan siswa"33

Untuk memastikan bahwa aktivitas dan habituasi keagamaan siswa berjalan dengan semestinya, maka bagi terdapat beberapa sangsi yang diberikan kepada siswa maupun orang tua siswa dari sekolah, seperti: memberikan surat teguran kepada orang tua siswa, memberi teguran secara lisan kepada siswa bersangkutan, memanggil orang tua siswa ke sekolah untuk mengkonvermasi permasalahan atau hambatan tidak terlaksananya aktivitas dan habituasi keagamaan siswa di rumah.

Informasi tersebut diperoleh dari hasil wawancara dengan Ibu Narsini, berikut kutipan hasil wawancaranya,

"Beberapa sangsi yang diberikan kepada siswa maupun orang tua siswa dari sekolah, seperti: memberikan surat teguran kepada orang tua siswa, memberi teguran secara lisan kepada siswa bersangkutan, memanggil orang tua siswa ke sekolah untuk mengkonfirmasi permasalahan atau hambatan tidak terlaksananya aktivitas dan habituasi keagamaan siswa di rumah"34

Kebiasaan terbentuk karena sesuatu yang dibiasakan, sehingga kebiasaan dapat diartikan sebagai perbuatan atau ketrampilan secara terusmenerus, secara konsisten untuk waktu yang lama, sehingga perbuatan dan keterampilan itu benar-benar bisa diketahui dan

\footnotetext{
${ }^{32}$ Ibu Istiqomah selaku orang tua salah seorang siswa, wawancara tanggal $29 \mathrm{Juli}$

${ }^{33}$ Ibu Sri Mulyani selaku guru kelas IV, wawancara tanggal 29 Juli 2018

${ }^{34}$ Ibu Narsini selaku Koordinator Waka PAI,wawancara tanggal 27 Juli 2018
} 
akhirnya menjadi suatu kebiasaan yang sulit ditinggalkan. Kebiasaan dapat juga diartikan sebagai gerak perbuatan yang berjalan dengan lancar dan seolah-olah berjalan dengan sendirinya. Perbuatan ini awalnya dikarenakan pikiran yang melakukan pertimbangan dan perencanaan, sehingga nantinya menimbulkan perbuatan yang apabila perbuatan ini diulang-ulang maka akan menjadi kebiasaan. ${ }^{35}$

\section{KONTRIBUSI AKTIVITAS DAN HABITUASI KEAGAMAAN} SISWA SDIT NIDAUL HIKMAH

Tujuan dari pendidikan adalah ingin membentuk karakter anak didik. Adanya pembiasaan agama yang dilaksanakan di sekolah diharapkan membawa titik perubahan pada siswa didik, artinya memberi kontribusi terhadap perkembangan siswa baik dari segi akademik ataupun non akademik.

a. Meningkatkan Kedisiplinan Siswa

Sekolah adalah alah satu tempat yang sangat strategis untuk membina dan mendidik karakter anak. Berbagai pelajaran akan ia dapatkan di sekolah, sehingga apa yang ia dapatkan akan berpengaruh terhadap pembentukan sikap dan perilakunya dengan rencana yang telah ditentukan oleh kurikulum". Hal ini berdasarkan pendapat Hakim" 36 bahwa "Hanya di sekolah dengan disiplin yang konsistenlah proses belajar dapat berlangsung dengan baik sesuai dn adanya disiplin yang konsisten, sekolah dapat menjalankan peranannya sbaagai lembaga pendidikan formal yang mampu meningkatkan kualitas tingkah laku siswa.

\footnotetext{
${ }^{35}$ Ahmad Susanto - Proses Habituasi Nilai Disiplin Pada Anak Usia Dini Dalam Kerangka Pembentukan Karakter Bangsa, Jurnal Sosioriligi, Volume 15 Nomor 1 (Maret 2017), 20-21.

${ }^{36}$ Hakim. 2012. Belajar secara efektif. Jakarta: Puspa Swara,2012,44-45.
} 
Hasil wawancara juga diperoleh informasi dari orang tua siswa, bahwa adanya aktivitas dan habituasi keagamaan yang dilaksanakan selama ini, mampu membuat putra putri mereka, lebih disiplin dalam menjalankan ibadah, selain itu juga mendorong putra putri mereka untuk lebih tertarik belajar mengaji dengan ustadz-ustadz atau kyai-kyai yang ada di kampung mereka, tanpa orang tua menyuruh putra putri mereka untuk melakukan aktivitas tersebut.

Berikut beberapa kutipan wawancara dengan orang tua siswa, "Setelah sekolah di SDIT Nidaul Hikmah anak saya lebih rajin untuk sholat berjamaah dengan orang tua....hal itu membuat saya sebagai orang tua merasa sangat bersyukur......."37

Pembelajaran dalam pengertian yang digunakan di sini adalah sebuah proses atau aktivitas yang menunjukkan pada proses perubahan yang diinginkan di dalam tingkah laku manusia. Hal tersebut sesuai pernyataan Zaenul ${ }^{38}$ menyebutkan bahwa " yang dapat dikembangkan untuk mendukung keberhasilan pendidikan karakter di sekolah adalah melalui proses secara bertahap, yaitu : (a) sosialisasi; (b) internalisasi; (c) pembiasaan, dan (d) pembudayaan di sekolah.”

b. Siswa Lebih Dekat Agama

Hasil penelitian juga menunjukkan, bahwa adanya aktivitas dan habituasi keagamaan yang dilaksanakan selama ini, mampu membuat siswa lebih disiplin dalam menjalankan ibadah, selain itu juga mendorong siswa untuk lebih tertarik belajar mengaji dengan ustadz-ustadz atau kyai-kyai yang ada di kampung

\footnotetext{
${ }^{37}$ Ibu Indah salah satu orang tua siswa, wawancara tanggal 29 Juli 2018

${ }^{38}$ F. Zaenul, 2012. Penididikan Karakter Berbasis Nilai dan Etika di Sekolah. Jogjakarta: Ar-Ruzz Media, 2012, 10.
} 
mereka, tanpa orang tua mereka menyuruhnya untuk melakukan aktivitas tersebut. Hal tersebut menunjukkan bahwa adanya aktivitas dan habituasi keagamaan di SD Nidaul Hikmah, siswa menjadi lebih disiplin dalam menjalankan ibadah, sementara itu bagi orang aktivitas dan habituasi keagamaan membantu mereka dalam mendidik putra putri mereka dekat dengan agama.

"Anak saya lebih semangat gak malas-malasan lagi kalo diajak ngaji sama teman-teman ketika di rumah" 39

"Anak saya sekarang suka main di masjid, dan jarang nonton $T V$ " 40

"Begitu adzan langsung sholat, gak usah disuruh-suruh lagi, tidak seperti dulu orang tua harus cerewet..." 41

Berdasarkan hasil wawancara tersebut maka dengan adanya aktivitas dan habituasi keagamaan siswa menjadikan siswa lebih disiplin dalam menjalankan ibadah, sementara itu aktivitas dan habituasi keagamaan bagi orang juga membantu mereka dalam mendidik putra putri mereka dekat dengan agama.

Hal ini menunjukkan bahwa siswa SDIT Nidaul Hikmah dalam menjalankan aktivitas keagamaan di sekolah sudah sesuai apa yang diprogramkan dari sekolah meskipun ada beberapa kendala yang dihadapi yaitu ada siswa yang belum memahami peraturan yang diterapkan atau saran dan prasarana yang belum memadai. Hal tersebut dapat kami peroleh dengan adanya CCTV yang dipasang di sekolah.Dari data dokumentasi CCTV yang kami pantau pada hari jumat tanggal 13 Juli 2018 pukul 9.45 terlihat siswa melaksanakan sholat di masjid. Dan pada pukul $12.15 \mathrm{kami}$ lihat siswa melaksanakan sholat berjamaah dimasjid. Hal tersebut 
menunjukkan bahwa aktivitas dan habituasi keagamaan di SDIT Nidaul Hikmah dilaksanakan oleh siswa.

\section{F. PEMBAHASAN}

Hasil penelitian juga menemukan beberapa kendala yang dihadapi dalam aktivitas dan habituasi keagamaan siswa. Adapun tersebut antara lain adalah: 1) Karena siswa masih taraf anak-anak maka dibutuhkan kesabaran yang tinggi dari guru koordinator dalam membimbing siswa, sebab yang namanya anak-anak dunia permainan masih melekat di benak mereka, sehingga terkadang mereka susah diatur saat diajari untuk bersikap tertib, 2) Siswa terkadang lupa bawa peralatan yang mendukung aktivitas keagamaan, misal: siswa lupa membawa rukuh, atau $\mathrm{Al}$ Qur'an, dan lain sebagainya, 3) Dukungan orang tua terkadang juga menjadi kendala, dimana terdapat siswa yang memiliki orang tua dengan status keduanya bekerja, sehingga orang tua jarang memberikan evaluasi terhadap aktivitas dan habituasi keagamaan pada putra-putri mereka, hal tersebut dapat dilihat dari banyaknya paraf yang kosong dari orang tua pada buku evaluasi, 4) Fasilitas yang disediakan sekolah juga menjadi kendala, sebab fasilitas juga masih terbatas, misal: untuk aktivitas wudhu siswa 1 (satu) kelas dengan jumlah 25 anak, membutuhkan waktu 30 menit, kondisi tersebut tentu mengganggu kelancaran dari aktivitas dan habituasi keagamaan siswa.

Hasil penelitian juga menemukan beberapa kendala yang dihadapi dalam aktivitas dan habituasi keagamaan siswa, antara lain: 1) Karena siswa masih taraf anak-anak maka dibutuhkan kesabaran yang tinggi dari guru koordinator dalam membimbing siswa, sebab yang namanya anakanak dunia permainan masih melekat di benak mereka, sehingga 
terkadang mereka susah diatur saat diajari untuk bersikap tertib, 2) Siswa terkadang lupa bawa peralatan yang mendukung aktivitas keagamaan, misal: siswa lupa membawa rukuh, atau Al Qur'an, dan lain sebagainya, 3) Dukungan orang tua terkadang juga menjadi kendala, dimana terdapat siswa yang memiliki orang tua dengan status keduanya bekerja, sehing ga orang tua jarang memberikan evaluasi terhadap aktivitas dan habituasi keagamaan pada putra-putri mereka, hal tersebut dapat dilihat dari banyaknya paraf yang kosong dari orang tua pada buku evaluasi, 4) Fasilitas yang disediakan sekolah juga menjadi kendala, sebab fasilitas juga masih terbatas, misal: untuk aktivitas wudhu siswa 1 (satu) kelas dengan jumlah 25 anak, membutuhkan waktu 30 menit, kondisi tersebut tentu mengganggu kelancaran dari aktivitas dan habituasi keagamaan siswa.

Untuk memastikan bahwa aktivitas dan habituasi keagamaan siswa berjalan dengan semestinya, maka bagi terdapat beberapa sangsi yang diberikan kepada siswa maupun orang tua siswa dari sekolah, seperti: memberikan surat teguran kepada orang tua siswa, memberi teguran secara lisan kepada siswa bersangkutan, memanggil orang tua siswa ke sekolah untuk mengkonvermasi permasalahan atau hambatan tidak terlaksananya aktivitas dan habituasi keagamaan siswa di rumah.

\section{G. KESIMPULAN}

Berdasarkan hasil penelitian dan pembahasan dapat disimpulkan bahwa:

1. Aktifitas keagamaan yang dilakukan di SDIT Nidaul Hikmah Kota Salatiga Tahun 2018 berupa: ceramah keagamaan, PHBI dan pengamalan ajaran agama berupa: shalat dhuha, takhfidz, dan shalat berjamaah (Dhuhur, dan Ashar). 
Jurnal Pendidikan Agama Islam Universitas Wahid Hasyim Semarang

2. Habituasi keagamaan yang dijalankan di SDIT Nidaul Hikmah dilaksanakan untuk membentuk karakter siswa. Habituasi Keagamaan tersebut adalah adanya model pembiasaan kedisiplinan untuk mencetak dan generasi unggulan yang berwawasan luas, bertauhid tinggi dan berkahluk karimah.

3. Kontribusi Aktivitas dan habituasi keagamaan siswa di SDIT Nidaul Hikmah antara lain :1) menanamkan pembiasaan beribadah, 2) menumbuhkan kedisiplinan, dan membiasakan siswa hidup dekat dengan agama, 3) pembiasaan anak berperilaku sesuai nilai- nilai ajaran Islam, jujur, bertanggung jawab dan berkarakter.

\section{DAFTAR PUSTAKA}

Alim, Muhammad. 2006. Pendidikan Agama Islam; Upaya Pembentukan Pemikirandan Kepribadian Muslim. Cet. I, Bandung: Remaja Rosdakarya.

Amilia, Fitri, "Pemahaman dan Habituasi untuk Membangun Kompetensi Menulis Praktis dan Ilmiah"Jurnal Bahasa, Sastra, dan Pengajarannya. (2018).

Arief, Armai. 2002. Pengantar Ilmu dan Metodologi Pendidikan Islam. Jakarta: Ciputat Press.

Binti Maunah, "Implementasi Pendidikan Karakter dalam Pembentukan Kepribadian Holistik Siswa". Jurnal Pendidikan Karakter. (2015).

Binti Maunah. 2009. Metodologi Pengajaran Agama Islam.Yogyakarta: Teras.

Bourdieu, P., 1992. Menyingkap KuasaSimbol. Terj.FauziFashri. Yogyakara: Jalan sutra. 
Jurnal Pendidikan Agama Islam Universitas Wahid Hasyim Semarang

Dirjen Bimbaga Islam. 1997. Petunjuk 354 Pelaksanaan Kurikulum Sekolah Menengah Umum/GBPP Mata Pelajaran Agama Islam. Jakarta: :Departemen Agama RI.

Djumhana, Hanna. 2001. Integrasi Psikologi dengan Islam Menuju Psikologi Islami, Yogyakarta: Yayasan Insan Kamil dan Pustaka Pelajar.

Hakim. 2012. Belajar secara efektif. Jakarta: Puspa Swara.

L Crow, A. Crow. 1989. PsikologiPendidikan, Nur Cahaya.

Majid, Abdul \& Dian Andayani. 2005. Pendidikan Agama Islam Berbasis Kompetensi. Bandung: Rosda Karya.

Munandar, Haris "Pola Pembinaan Keagamaan Di SMA Plus Boarding School Astha Hannas Subang", Jurnal Tarbiyah, (2018).

P. McPhail, Social and Moral Education, London, Basil Black Well, 1982.

Poerwadarmint, W. J.S. 1984. Kamus Umum Bahasa Indonesia, Jakarta : Balai Pustaka.

Purwanto, M. Ngalim. 2002. Ilmu Pendidikan Teoritis dan Praktis. Bandung : Remaja Rosda karya.

Republik Indonesia. Peraturan Pemerintah Nomor 55 Tahun 2007.Tentang Pendidikan Agama dan Pendidikan Keagamaan. (22 April 2010).

Republik Indonesia. 2007. Undang-UndangNomor 20 Tahun 2003 tentang Sistem Pendidikan Nasional. Jakarta: Departemen Agama R.I., Direktorat Jenderal Pendidikan Islam.

Sadiah, Dewi, "Pengembangan Model Pendidikan Nilai-Nilai Keberagamaan Dalam Membina Kepribadian Sehat", Jurnal Penelitian Pendidikan (2010).

Soekanto,Soejono. 1989. KamusSosiolog.Rajawali Press, Jakarta, 1989.

Sueyabrata, Sumadi. 1984. PsikologiPendidikan. Jakarta: Rajawali press.

Sugiyono. 2006. Statistika Untuk Penelitian.Bandung: Alfabeta. 
Jurnal Pendidikan Agama Islam Universitas Wahid Hasyim Semarang

Susanto, Ahmad. "Proses Habituasi Nilai Disiplin Pada Anak Usia Dini Dalam Kerangka Pembentukan Karakter Bangsa", Jurnal Sosioriligi, Volume 15 Nomor 1 (Maret 2017).

Syah, Muhibin. 2003. Psikologi Pendidikan dengan Pendekatan Baru. Bandung: Remaja Rosda Karya.

Zaenul, F. 2012. Penididikan Karakter Berbasis Nilai dan Etika di Sekolah. Jogjakarta: Ar-Ruzz Media. 